\title{
Cellular tropism exhibited by human T lymphotropic virus type 1 (HTLV-1) and type 2 (HTLV-2)
}

\author{
Priya Kannian, Han Yin, Rami Doueiri, Patrick L Green ${ }^{*}$ \\ From 15th International Conference on Human Retroviruses: HTLV and Related Viruses \\ Leuven and Gembloux, Belgium. 5-8 June 2011
}

\section{Background}

HTLV-1 predominantly transforms CD4+T cells in vitro and induces leukemia and neurological disease in vivo, whereas HTLV-2 shows a preference for CD8+T cell transformation in vitro with limited in vivo pathology. To better understand cellular tropism of HTLV-1 and HTLV-2 early after in vivo infection we determined proviral load and gene expression kinetics of these viruses in purified $\mathrm{CD} 4+$ and $\mathrm{CD} 8+\mathrm{T}$ cells from newly infected rabbits.

\section{Materials and methods}

New Zealand White rabbits (four/group) were inoculated intravenously with HTLV-1 (Ach), HTLV-2 (pH6neo), and control irradiated producer cells. Blood was collected pre- (week 0 ) and post-inoculation (weeks $1,2,4,6,8, \& 12$ ) for detecting antibody responses using line blot assay, and proviral load and viral gene expression in purified $\mathrm{CD} 4+$ and $\mathrm{CD} 8+\mathrm{T}$ cells using real-time PCR.

\section{Results}

HTLV-1 and HTLV-2 infected rabbits seroconverted and had detectable proviral loads in both CD4+ and CD8+T cells by 1 wk post infection. HTLV-1 showed slightly higher $\mathrm{CD} 4+\mathrm{T}$ cell proviral loads early, but overtime the virus was detected at higher levels in CD8+T cells. In general HTLV-2 proviral loads were lower than HTLV-1 and throughout the experimental time course the predominant infected cell was the CD8+T cell. HTLV-1 gene expression levels (gag/pol, tax/rex, and hbz) peaked early in $\mathrm{CD} 4+\mathrm{T}$ cells, but overall expression levels over time were higher in CD8+T cells. HTLV-2

\footnotetext{
* Correspondence: green.466@osu.edu

* Correspondence: green.466@osu.edu
Center for Retrovirus Research, Department of Veterinary Biosciences, and Comprehensive Cancer Center and Solove Research Institute, The Ohio State University, Columbus, $\mathrm{OH}, 43210$, USA
}

(c) 2011 Kannian et al; licensee BioMed Central Ltd. This is an open access article distributed under the terms of the Creative Commons Attribution License (http://creativecommons.org/licenses/by/2.0), which permits unrestricted use, distribution, and reproduction in any medium, provided the original work is properly cited. gene expression was detected in both $\mathrm{CD} 4+$ and $\mathrm{CD} 8+\mathrm{T}$ throughout the study. Viral determinants of tropism with emphasis on Env will also be discussed.

\section{Conclusions}

In the infected rabbit, HTLV-1 shows an early preference for CD4+T cells, but over the 12 wk study the majority of cells harboring and expressing the virus are $\mathrm{CD} 8+\mathrm{T}$ cells. In contrast, in this early stage of infection, HTLV-2 reveals a preference for CD8+T cells. We speculate that this differential tropism between HTLV-1 and HTLV-2 contributes to the distinct pathobiology of these two related viruses.

Published: 6 June 2011

doi:10.1186/1742-4690-8-S1-A176

Cite this article as: Kannian et al:: Cellular tropism exhibited by human T lymphotropic virus type 1 (HTLV-1) and type 2 (HTLV-2). Retrovirology 20118 (Suppl 1):A176.

Submit your next manuscript to BioMed Central and take full advantage of:

- Convenient online submission

- Thorough peer review

- No space constraints or color figure charges

- Immediate publication on acceptance

- Inclusion in PubMed, CAS, Scopus and Google Scholar

- Research which is freely available for redistribution Submit your manuscript at
www.biomedcentral.com/submit C BioMed Central 